\title{
Evaluation of Agro-Industrial By Products as Potential Local Feed for Ruminant Animals: Chemical Composition, Fiber Fractions and In Vitro Rumen Fermentation
}

\author{
Said Mirza Pratama ${ }^{1}$, Sitti Wajizah ${ }^{2}$, Anuraga Jayanegara ${ }^{3}$ and Samadi ${ }^{2 *}$ \\ ${ }^{1}$ Magister Program of Animal Husbandry Department, The Faculty of Agriculture, Syiah Kuala University, Banda Aceh \\ ${ }^{2}$ Animal Husbandry Department, The Faculty of Agriculture Syiah Kuala University, Banda Aceh \\ ${ }^{3}$ Faculty of Animal Science, Bogor Agricultural University, Bogor \\ Corresponding author email: samadi177@unsyiah.ac.id
}

\begin{abstract}
Animals are considered as source of protein should be improved their productivity with the minimum cost production. Agro-industrial by products have been used as animal feed to reduce feed cost. The purpose of this study is to evaluate agro-industrial by product in Aceh as potential local feed for ruminant animals based on chemical composition, fiber fraction and in vitro rumen fermentation. There were eight sources of agro-industrial by products (sago residues, coconut meal, soybean-ketchup by product, coffee pulp, cacao pod, sago tree, corncob, and rice brand) which were collected from 3 different locations in Aceh. All agro-industrial by product samples were dried at $60^{\circ} \mathrm{C}$ for $24 \mathrm{~h}$ and ground to pass a $1 \mathrm{~mm}$ sieve. Grounded samples were analyzed to determine chemical composition, fiber fractions and in vitro rumen fermentation. Incubation was conducted at temperature $39^{\circ} \mathrm{C}$ for $48 \mathrm{~h}$ in water bath with three replicates. Data for in vitro rumen fermentation were statically calculated by using SPSS differences between treatments were stated $(P \leq 0.05)$ by using Duncan Multiple Range Test (DMRT). The results indicated that agro industrial by product from coconut meal, ketchup residues, coffee by product, cacao by product, and rice brand can be used as source of protein and industrial by product from sago by product, sago tree and corncob can be used as source of energy. Neutral detergent insoluble CP (NDICP) and Acid detergent insoluble CP (ADICP) were relatively high for sago by product, sago tree and rice brand but relatively low for cacao by product and corncob. The value of incubated $\mathrm{pH}$ for most feed samples was in the normal range. In vitro dry matter digestibility (IVDMD) and in vitro organic matter digestibility (IVOMD) were significantly difference $(P \leq 0.05)$ each agro-industrial by products with the highest for sago and the lowest for coffee by product. In conclusion, agro-industrial by products had a potential feed for ruminant animals both as protein and energy sources. However, feed ingredients with high fiber content and low degradability, further treatments such as physical, chemical and biological treatments were required to improve the feed quality.
\end{abstract}

Keywords: Agro-industrial by products, ruminant, feed, and in vitro.

\begin{abstract}
Abstrak. Ternak merupakan sumber protein hewani perlu ditingkatkan produksinya dengan biaya minimal dan memanfaatkan limbah industri pertanian sebagai sumber bahan pakan. Tujuan dari penelitian ini adalah mengevaluasi limbah industri pertanian sebagai sumber bahan pakan lokal ruminansia yang potensial di Aceh berdasarkan komposisi kimia, fraksi serat dan kecernaan in vitro. Delapan sumber bahan pakan yang berasal dari limbah industri pertanian (ampas sagu, bungkil kelapa, ampas kecep, ampas kopi, kulit coklat, gerusan sagu, tongkol jagung dan dedak) dari tiga lokasi berbeda di Aceh digunakan dalam penelitian ini. Sampel yang akan dianalisa (kandungan nutrisi, fraksi serat dan fermentasi rumen secara in vitro) terlebih dahulu dikeringkan selama $60^{\circ} \mathrm{C}$ selama 24 jam dan diigiling dengan ukuran $1 \mathrm{~mm}$. Inkubasi dilakukan pada suhu $39^{\circ} \mathrm{C}$ selama 48 jam dalam water bath terdiri dari 3 ulangan. Data in vitro dianalisa secara statistik dengan mnggunakan SPPSS. Perbedaan antar perlakukan dinyatakan pada $(P \leq 0.05)$ dilanjutkan dengan uji jarak berganda Duncan. Dari hasil analisa data didapatkan bahwa produksi limbah pertanian dari bungkil kelapa, limbah kecap, limbah kopi, limbah coklat dan dedak sebagai sumber protein, sementara limbah sagu, gerusan sagu dan tongkol jagung dapat digunakan sebagai sumber energi. Komposisi NDICP dan ADICP relatif tinggi pada limbah sagu, gerusan sagu dan dedak, namun relatif rendah pada limbah coklat dan tongkol jagung. Nilai pH pada semua bahan limbah pakan dari hasil fermentasi berada dalam kisaran normal. Kecernaan bahan kering dan dan kecernaan bahan organik setiap bahan pakan berbeda nyata $(P \leq 0.05)$ pada setiap bahan pakan limbah industri pertanian yang tertinggi pada pada ampas sagu dan yang terendah pada limbah kopi. Dari hasil penelitian dapat disimpulkan bahwa limbah industri pertanian lokal di Aceh dapat digunakan sebagai sumber bahan pakan ternak ruminansia baik sumber protein maupun sumber energi. Namun demikan, bahan pakan yang tinggi kadar serat dan rendah daya cerna perlu adanya perlakuan fisik, kimia dan biologi untuk meningkatkan kualitas bahan pakan dari limbah.
\end{abstract}

Kata kunci: Limbah industri pertanian, ruminansia, pakan dan in vitro 


\section{Introduction}

Sustainability with the principle of zero waste production is very important in facing the growth of world population up to 9 million in 2050. Animals is considered as source of protein should be improved their productivity with the minimum cost production. However, land cultivation for feed resource decreased due to land use for other purposes and feed production over the worldwide tended to reduce as result of climate change (Smith and Gregory, 2013). Therefore, efforts to find sources for alternative feedstuffs should be implemented as strategies to meet the need of feedstuffs in the future.

Agro-industrial by products as an alternative feedstuff have been used as animal feed to reduce feed cost (Mirzaei-Aghsaghali and Maheri-Sis, 2008; Samadi et al., 2015a; Samadi et al., 2015b). Agro-industrial by products is also a potential solution to provide protein and calories for animal production in worldwide. Utilization of agro-industrial by products supported political and social pressure to reduce pollution. Besides that, agro-industrial by products considered as residues can be utilized for other useful products like feedstuffs, fuel or fertilizer. Amongst them, feedstuffs had more economical values due to high cost of conventional feedstuffs. Even thought, residue from agro-industries contain low nitrogen and high fiber contents (Aregheore, 2000), ruminants have ability to utilize fibers for their maintenance, growth, production and reproduction because of their rumen microbes.

Aceh Province has a number of agroindustries producing potential agro-industrial residues as alternative promising local ruminant feedstuffs. Several agro-industrial by product such as sago residues, coconut meal, ketchup residues, coffee pulp, cacao pod, sago tree, corncob, and rice brand have been identified in Aceh Province. Information relating to some potency of local feed as animal feedstuffs has been published (Wahyono and Hardiyanto, 2008; Samadi et al., 2010) with limited data for diet formulation. As a result, feed composition from National Research Council (NRC) is still used as reference for feed formulation in Indonesia. However, nutritional contents of feedstuffs highly varied depending on soil condition, climate and other environmental factors (Assefa and Ledin, 2001) and are not suitable to be used in animal feed formulation due to different nutritive values. Therefore, determination of nutritive values for local feedstuffs is required to support database for nutritionists in formulating feed by using local feedstuffs.

The feed quality was not determined not only by chemical composition but by other parameters as well such as fiber fraction and digestibility. Samadi and Yu (2011) and Samadi et al. (2013) determined energy and protein requirement for ruminant based on Cornell Net Carbohydrate Protein System (CNCPS) in which feed was divided in several carbohydrate and protein fractions. The purpose of this study is to evaluate agro-industrial by products as potential local feed for ruminant animals based on chemical composition, fiber fractions and in vitro rumen fermentation.

\section{Materials and Method}

\section{Sample Collection and Preparation}

Eight sources of agro-industrial by products (sago residues, coconut meal, soybean-ketchup by product, coffee pulp, cacao pod, sago tree, corncob, and rice brand) in this study were collected from 3 different locations in Aceh (Great Aceh, Bireun and North Aceh). Shortly after collection, all samples were kept in freezer $\left(-20^{\circ} \mathrm{C}\right)$ for further analysis. Then, all agroindustrial by product samples were dried at $60^{\circ} \mathrm{C}$ for $24 \mathrm{~h}$ and ground to pass a $1 \mathrm{~mm}$ sieve by using hammer mill. All ground samples were then used for further chemical analysis to 
determine chemical composition, fiber fraction and in vitro rumen fermentation.

\section{Chemical composition determination}

Chemical composition of samples were determined by proximate analysis consisting of determination of dry matter (DM), ash, organic matter (OM), crude protein (CP), ether extract (EE), and crude fiber (CF) based on AOAC procedures (AOAC, 2005). For a short information, DM content was determined by drying samples in an oven set at $105^{\circ} \mathrm{C}$ for $24 \mathrm{~h}$. The content of ash was determined by burning samples in a furnace at $500^{\circ} \mathrm{C}$ for $3 \mathrm{~h}$. OM was determined by calculating the difference between DM and ash. CP was determined based on Kjeldahl method with the following consecutive procedures; destruction, distillation and titration. Determination of CF was conducted by sequential boiling of samples in acid and alkali solutions each for $30 \mathrm{~min}$. EE was determined by applying soxhlet extractor and petroleum ether to extract the fat content of samples.

\section{Fiber Fraction determination}

The method of Van Soes et al. (1991) were applied to determine the content of neutral detergent fiber (NDF) and acid detergent fiber (ADF). Sample were boiled in neutral detergent and acid detergent solutions for $1 \mathrm{~h}$ in sequential. Analysis of NDF was determined without $\alpha$-amylase and sodium sulfite, and the value was expressed exclusive of residual ash. Determination of neutral detergent insoluble $\mathrm{CP}$ (NDICP) and acid detergent insoluble CP (ADICP) contents was by sing using method as described by Licitra et al. (1996). Samples to determine NDICP and ADICP were obtained from residual NDF and ADF analysis. All chemical composition and fiber fraction determination were performed in duplicate.

\section{In vitro Rumen Fermentation}

In vitro rumen fermentation was performed at the Laboratory of Nutrition and Dairy
Science, Nutrition and Feed Technology Department, IPB Bogor. The procedure of Theodorou et al. (1994) method were applied to determine IVDMD and IVOMD. Briefly, rumen fluid was collected in the morning before feeding through a rumen fistulated cow. Rumen fluid was filtered with four layers of gauze before using. A $125 \mathrm{ml}$ serum bottle was prepared to fill in 0.75 sample and add $75 \mathrm{ml}$ buffered rumen fluid with the ratio of rumen fluid : buffer $(1.4 \mathrm{v} / \mathrm{v})$. Incubation was taken place in a water bath with the temperature of $39^{\circ} \mathrm{C}$ for $48 \mathrm{~h}$. After $48 \mathrm{~h}$ incubation. Supernatant obtained was analyzed to determine $\mathrm{pH}$ by using a $\mathrm{pH}$ meter. Residue was further incubated with $75 \mathrm{ml}$ pepsin- $\mathrm{HCl}$ $0.2 \mathrm{~N}$ solution for another $48 \mathrm{~h}$ (Tilley and Terry, 1963). IVDMD and IVOMD were determined by subtracting residues of $D M$ and OM from initial prior to fermentation, respectively. The in vitro incubation was conducted in three runs and two serum bottles represented for each run. In this experimental, different in vitro runs was considered as block (replicates).

\section{Data analysis}

All data were analyzed by using analysis of variance with the following statistical model:

$$
Y i j=\mu+\alpha i+\beta j+\varepsilon i j
$$

Where; Yij is the observed value, $\mu$ is the overall mean, $\alpha i$ is the treatment effect, $\beta j$ is the block. differences between treatments were stated $(P<0.05)$ by using Duncan Multiple Range Test (DMRT). The statistical analysis was performed by using SPSS software version 9.1.

\section{Results and Discussion}

\section{Chemical Composition}

Chemical composition of agro-industrial by products (sago residues, coconut meal, ketchup residues, coffee pulp, cacao pod, sago tree, corncob, and rice bran) as potential local feed for ruminant animals in Aceh Province is 
presented in the Table 1. Dry matter content of agro-industrial from this study was from $82.45 \%$ to $91.68 \%$ with the highest organic content $(88.20 \%)$ in corncob and the lowest organic content (51.70\%) in ketchup residues. The highest content of ash in this study due to salty ketchup process. The ash content of corncob in this study was also higher compared to NRC (2000) and Yulistiani et al. (2012) with the ash content of $1,8 \%$ and $1,2 \%$ respectively. The highest protein content of agro industrial product in this study was $16.53 \%$ in coconut meal. It was lower compared to data published by NRC (2000) and Agustono et al. (2017). In this study, sago residues had the lowest protein content $(1.10 \%)$ due to sago as source of carbohydrate. Kleden and Mariana (2018) stated that agro-industrial by product contained high in crude fiber and low in protein. Cacao pod had the highest of crude fiber content (29.6\%). The results was different from Nuraini and Mahata (2009). Assefa and Ledin (2001) stated that nutritional contents of feedstuffs highly different depending on soil condition, climate and other environmental factors and to formulate feedstuffs as animal feed should be firstly analyzed. It should be also considered that some agro-industrial by product contained anti-nutritional factor as example of theoromin in cacao pod (Aregheore, 2000).

In our study, coconut meal contained the highest lipid (12.55\%). Our lipid content result was similar reported by Agustono et al. (2017) with the lipid content of $12.55 \%$. Coconut meal was the result of palm oil and usually still contained lipid in the residues. In our study, the lowest lipid content was in the sago residue with the amount of $0.24 \%$. The highest content of nitrogen free extract (NFE) in our study was sago trees with the amount of 91.86. We used sago trees as part in our study since farmers in Aceh utilized this part of feedstuffs in their feed formulation. It could be source of information for the farmers. The lowest NFE was 34.56 in the ketchup residues. NFE content in the feedstuff is highly dependent on the content of crude protein, ash, crude fiber and crude lipid.

Table 2 shows fiber fraction of agroindustrial by products (sago residues, coconut meal, ketchup residues, coffee pulp, cacao pod, sago tree, corncob, and rice bran) as potential local feed for ruminant animals in Aceh Province. The results of the study indicated that cacao pod contained the highest level of NDF with $81.70 \%$ and coffee residues contained the lowest level of NDF with $38.58 \%$. The NDF contain of cacao pod in our results was in accordance with the results from Laconi and Jayanegara (2015) with the amount of $80.70 \%$. Compared with soybean as source of protein in animal feed, NDF content in agro-industrial by products was much higher (Samadi and Yu, 2011).

Ghodrat et al. (2017) stated that ADF in feedstuffs consisting of cellulose, lignin and heat-damaged protein in which protein was bound with lignin. NDF uses as fast method to measure fiber as substitution for crude fiber measurement. Among agro-industrial by products in our study, rice bran contained the highest of ADF content with the amount of $50.81 \%$ and sago had the lowest with the amount of $9.30 \%$. ADF content of rice bran in our study was higher compared to Ghodrat et al. (20170 with the amount of $44.80 \%$. MirzaeiAghsaghali (2008) presented some agroindustrial by products for ruminant animal including fiber fraction and conclude that agroindustrial by product had economical worthwhile due to high cost of conventional feed. ADF content containing agro-industrial by products higher compared with source of protein in feed such as soybean (Samadi and Yu, 2011).

Fiber reflected nutritional values of feedstuffs consisting of highly fermentable, less fermentable and purified fiber such as cell 
Said Mirza Pratama, et al/Animal Production. 20(3):155-164, 2018

Accredited by Kemenristek Dikti No 32a/E/KPT/2017. ISSN 1411-2027

Table 1. Nutritive values of agro-industrial by products (sago residues, coconut meal, ketchup residues, coffee pulp, cacao pod, sago tree, corncob, and rice bran) as potential local feed for ruminant animals in Aceh Province

\begin{tabular}{|c|c|c|c|c|c|c|c|}
\hline $\begin{array}{l}\text { Agro-industrial by } \\
\text { Products }\end{array}$ & $\begin{array}{l}\text { DM } \\
(\%)\end{array}$ & $\begin{array}{l}\mathrm{OM} \\
(\%)\end{array}$ & $\begin{array}{c}\text { Ash } \\
\text { (\%DM) }\end{array}$ & $\begin{array}{c}\mathrm{CP} \\
(\% \mathrm{DM})\end{array}$ & $\begin{array}{c}\mathrm{CL} \\
(\% \mathrm{DM})\end{array}$ & $\begin{array}{c}\mathrm{CF} \\
(\% \mathrm{DM})\end{array}$ & $\begin{array}{l}\text { NFE } \\
\text { (\%BK) }\end{array}$ \\
\hline Sago Residues & 89.89 & 85.76 & 4.13 & 1.99 & 0.48 & 5.72 & 87.68 \\
\hline Coconut Meal & 88.48 & 81.06 & 7.42 & 16.53 & 12.55 & 10.56 & 52.94 \\
\hline Ketchup Residues & 82.45 & 51.7 & 30.75 & 15.42 & 10.79 & 8.48 & 34.56 \\
\hline Coffee Pulp & 87.09 & 73.6 & 13.49 & 8.58 & 0.93 & 14.54 & 62.46 \\
\hline Cacao Pod & 87.23 & 75.61 & 11.62 & 9.66 & 0.42 & 29.3 & 49 \\
\hline Sago Trees & 89.6 & 85.83 & 3.77 & 1.1 & 0.24 & 3.03 & 91.86 \\
\hline Corncob & 91.2 & 88.2 & 3 & 4.01 & 0.58 & 26.97 & 65.44 \\
\hline Rice bran & 91.68 & 81.42 & 10.26 & 8.6 & 10.62 & 10.63 & 59.89 \\
\hline
\end{tabular}

DM:Dry Matter, OM: Organic Matter, CP: Crude Protein, CL: Crude Lipid, CF; Crude Fiber and NFE: Nitrogen Free Extract 


\section{Fiber Fraction}

Table 2. Fiber fraction of agro-industrial by products (sago residues, coconut meal, ketchup residues, coffee pulp, cacao pod, sago tree, corncob, and rice bran) as potential local feed for ruminant animals in Aceh Province

\begin{tabular}{lcccc}
\hline $\begin{array}{c}\text { Agro-industrial by } \\
\text { Products }\end{array}$ & $\begin{array}{c}\text { NDF } \\
\text { (\% DM) }\end{array}$ & $\begin{array}{c}\text { ADF } \\
(\% \mathrm{DM})\end{array}$ & $\begin{array}{c}\text { NDICP } \\
(\% \mathrm{CP})\end{array}$ & $\begin{array}{c}\text { ADICP } \\
(\% \mathrm{CP})\end{array}$ \\
\hline Sago residues & 77.1 & 17.49 & 2.17 & 5.42 \\
Coconut meal & 27.99 & 15.4 & 1.54 & 1.53 \\
Ketchup residues & 58.43 & 31.79 & 1.71 & 0.91 \\
Coffee pulp & 38.58 & 21.04 & 1.37 & 1.14 \\
Cacao pod & 81.07 & 41.69 & 0.70 & 0.52 \\
Sago trees & 63.95 & 9.3 & 4.94 & 5.20 \\
Corncob & 58.65 & 49.14 & 0.99 & 1.64 \\
Rice bran & 57.19 & 50.81 & 3.34 & 2.52 \\
\hline
\end{tabular}

ADF, Acid detergent fiber; ADICP, Acid detergent insoluble crude protein; NDF, Neutral detergent fiber, NDICP, Neutral detergent insoluble crude protein.

wall. Protein binding to cell wall such as neutral detergent insoluble crude protein (NDICP) dan acid detergent insoluble crude protein (ADICP) was not available for animal as source of energy and protein. Samadi et al. (2013) stated that the content of NDICP and ADICP in the feedstuffs effected rumen degradation based on in vitro study. According to CNCPS system, characteristic of proteins in the feedstuffs was partitioned based on solubility and degradation in the rumen; rapidly degraded protein, slow degraded protein and not available protein. In our study, the content of NDICP and ADICP was mostly under $5 \%$, except for several feedstuffs such as sago residues and sago tress containing ADICP of $5.42 \%$ and $5.20 \%$ respectively.

\section{In vitro Rumen Fermentation}

The value of $\mathrm{pH}$, in vitro dry matter digestibility (IVDMD) and in vitro organic matter digestibility (IVOMD) agro-industrial by products (sago residues, coconut meal, ketchup residues, coffe pulp, cacao pod, sago tree, corncob and rice bran) as potential local feed for ruminant animals in Aceh Province after rumen fermentation are presented in
Figure 1, 2 and 3 respectively. Based on the statistical results, agro-industrial by products were significantly different $(P>0.01)$ amongst local feedstuffs for $\mathrm{pH}$, IVDMD and IVOMD. The value of $\mathrm{pH}$ had an important role in degradability process of feedstuff in the rumen and supported the growth of rumen microbes. The highest of $\mathrm{pH}$ rumen agroindustrial by products in our study was 7.0 and the lowest was 6.6 for coffee residues and sago trees respectively. The value of $\mathrm{pH}$ was still in the optimal of microbe growth. According to Kopecny and Wallace (1982) proteolitic enzyme worked optimally in the range of $\mathrm{pH}$ 5.5-7.0. Study conducted by Cardozo et al. (2002) comparing to kind of feedstuffs high forage vs high concentrate with the $\mathrm{pH}$ from 4.9 to 7.0 concluded that degradation of protein was reduced along with decrease of $\mathrm{pH}$ value.

In addition, study conducted by Lana et al. (1998) also indicated that reduce of $\mathrm{pH}$ from 6.5 to 5.7 reduced the concentration of ammonia in the rumen, but this only for the cattle fed $100 \%$ forage. Wajizah et al., (2015) reported that fermented oil palm fronds by Aspergilus niger with different soluble 
carbohydrate had $\mathrm{pH}$ value with the range of 6.80-6.90. The research conducted by Devant et al. (2001) by using soybean mean and heatprocessed soybean meal with the concentration of 60:40 (forage : concentrate) and beef cattle feed with the ratio of 10:90 (forage:concentrate) concluded that degradation of protein was lower in the beef cattle beef and $\mathrm{pH}$ was not only influencing reduction of protein degradation. In our study, lower $\mathrm{pH}$ in sago trees compared to others since not structural carbohydrates such as starch were quickly fermented to lactic acids and reduced the $\mathrm{pH}$ value.

The percentage of IVDMD in our study was in the range of $46.89 \%-92.20 \%$. Coffee residues had the lowest of IVDMD (46.98\%) due to high content of crude fiber in the coffee residues. Agro-industrial by products has been used to replace conventional feed due to high cost of conventional feed. Study conducted by Seo et al. (2015) concluded that spent ground coffee can be used as alternatives to conventional feed by improving their nutrition composition and reduce cost. Fermentation of agro-industrial by product was able to improve production and bioactive content (Acevedo et al., 2013), resulted in improving of feed digestibility. The value of IVOMD in our study was $42.27 \%-95.26 \%$. The high content of IVOMD in some of ingredients in our study due to high starch content in sago trees. Formulation of cattle feed by using ground sago trees was intensively applied as one of the ingredients in ruminant feed formulation in Aceh. Fermentation of sago residues improved IVDMD and IVOMD to $19.34 \%$ to $22.19 \%$ due to feed fraction alteration after fermentation.

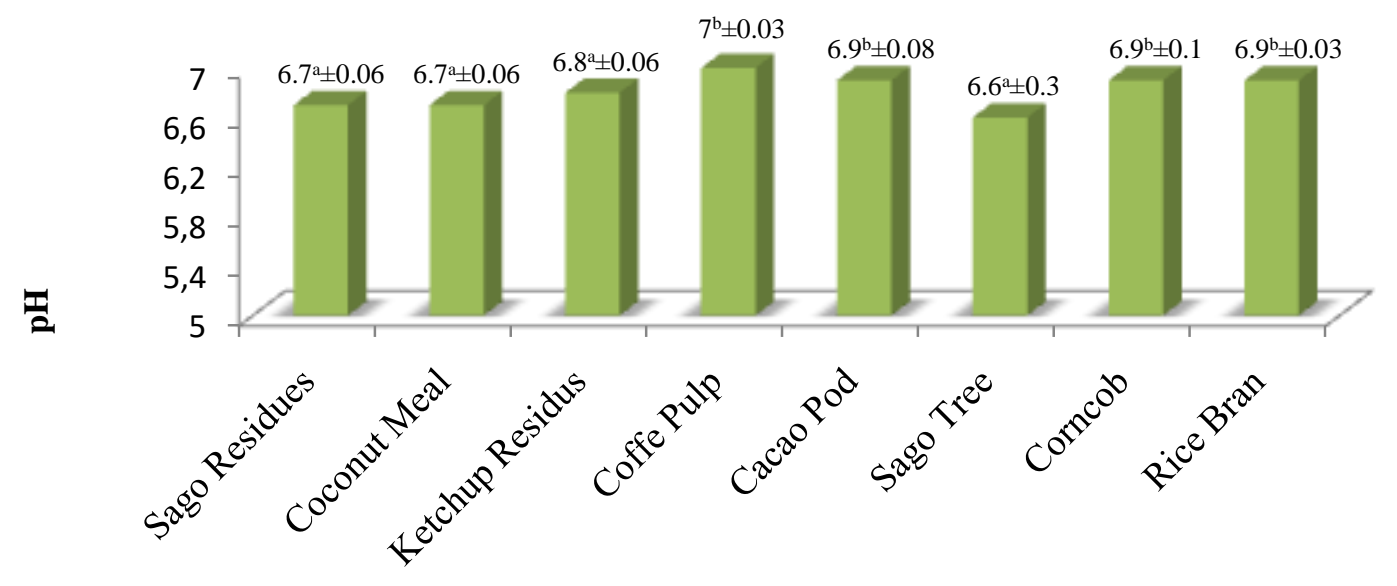

Agro-industrial By Products

Figure 1. pH values of agro-industrial by products (sago residues, coconut meal, ketchup residues, coffe pulp, cacao pod, sago tree, corncob and rice bran) as potential local feed for ruminant animals in Aceh Province after rumen fermentation. 


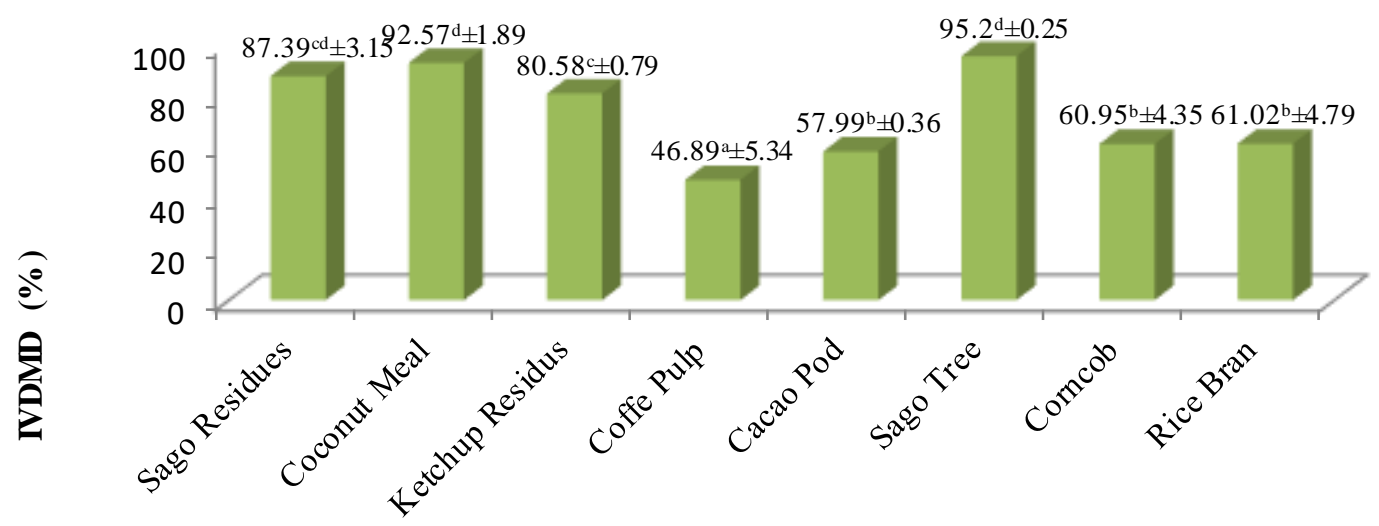

Agro-industrial By Products

Figure 2. IVDMD of agro-industrial by products (sago residues, coconut meal, ketchup residues, coffe pulp, cacao pod, sago tree, corncob and rice bran) as potential local feed for ruminant animals in Aceh Province after rumen fermentation.

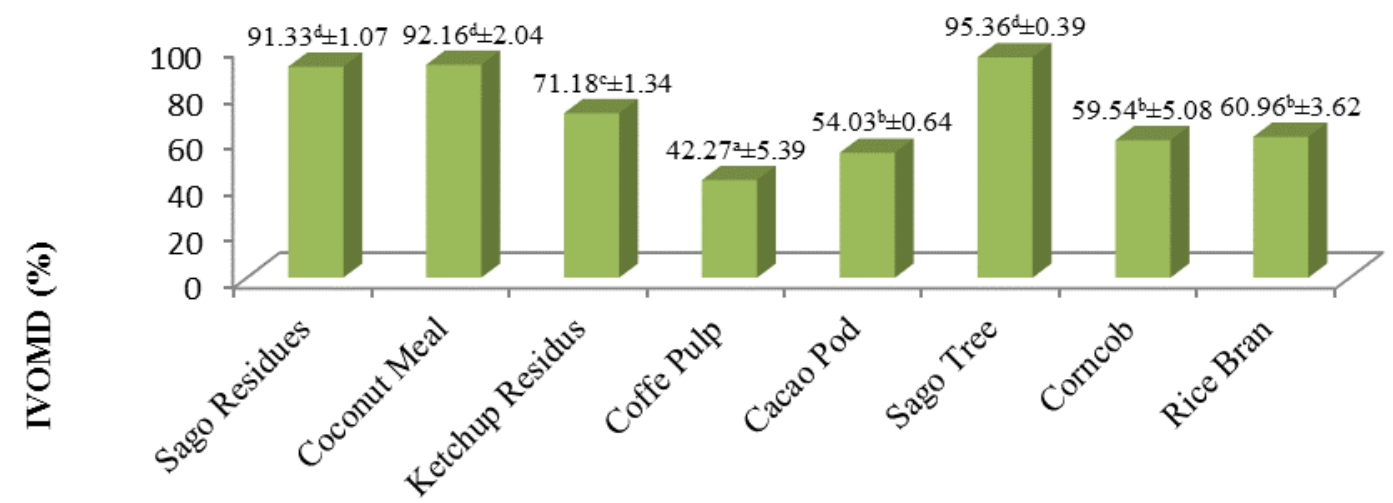

Agro-industrials By Product

Figure 3. IVOMD of agro-industrial by products (sago residues, coconut meal, ketchup residues, coffe pulp, cacao pod, sago tree, corncob and rice bran) as potential local feed for ruminant animals in Aceh Province after rumen fermentation.

\section{Conclusions}

In conclusion, agro-industrial by products had a potential feed for ruminant animals both as protein and energy sources. However, feed ingredients with high fiber content and low degradability, further treatments such as physical, chemical and biological treatments were required to improve the feed quality.

\section{Acknowledgement}

This study was supported by Syiah Kuala University Grant under Profesorship Scheme in 2018. Authors thanks to group research team Ilham and Hanafiah for good cooperation during research activities both in the field and laboratory analysis. Thanks also to Ms. Dian Anggraeni, Ms. Endang Rosmalia, Ms. Eneh Maisaroh and Ms. Ratih Windyaningrum at IPB for help in chemical analysis.

\section{References}

Acevedo F, M Rubilar, E Scheuermann, B Cancino, G Uquiche, M Garcés, K Inostroza and C Shene. 2013. Spent coffee grounds as a renewable source of bioactive compounds. Journal of Biobased Materials and Bioenergy 7:420-428

Agustono, B, M Lamid, A Ma'ruf, dan MT Elziyad. 2017. Identifikasi Limbah Pertanian Dan Perkebunan Sebagai Bahan Pakan 
Inkonvensional Di Banyuwangi. Jurnal Medik Veteriner, 1(1): 12-22.

AOAC (Association of Official Analytical Chemists). 2005. Official Methods of Analysis. 18th ed. AOAC International, Arlington, VA, USA.

Aregheore, EM. 2000. Crop residues and agroindustrial by products in four pacific island countries: availability, utilization and potential value in ruminant nutrition. Asian-Australian Journal Animal Science 13 (Supplement): B 266269.

Assefa, G and I Ledin. 2001. Effect of variety, soil type and fertiliser on the establishment, growth, forage yield, quality and voluntary intake by cattle of oats and vetches cultivated in pure stands and mixtures. Animal Feed Science and Technology 92(1-2): 95-111.

Cardozo, PS Calsamiglia, A Ferret. 2000. Effect of $\mathrm{pH}$ on microbial fermentation and nutrient flow in a dual flow continuous culture system Journal of Dairy Science 83 (Suppl. 1):265.

Devant, MA Ferret, S Calsamiglia, R Casals, J Gasa. 2001 Effect of nitrogen source in highconcentrate low-protein beef cattle diets on microbial fermentation studied in vivo and in vitro. Journal of Animal Science 79:1944-1953.

Ghodrat, AA Yoghobar, Y Ebrahimnezhad, HA Shahryar and A Ghorbani. 2017. In vitro binding capacity of organic (wheatbran and rice bran) and inorganic (parlite) source for $\mathrm{Mn}, \mathrm{Zn}, \mathrm{Cu}$ and Fe. Journal of Applied Animal Research 45(1): 80-84.

Kleden, M and M Mariana. 2018. Upaya Pendayagunaan Limbah Pertanian Sebagai Pakan Unggulan Musim Kemarau Di Lahan Kering. JPM (Jurnal Pemberdayaan Masyarakat) 3 (1), 213-21.

Kopecny, J, and RJ Wallace. 1982. Cellular location and some properties of proteolytic enzymes of rumen bacteria. Applied Environment and Microbiology 43:1026-1033.

Laconi, EB, and A Jayanegara. 2015. Improving Nutritional Quality of Cocoa Pod (Theobroma cacao) through Chemical and Biological Treatments for Ruminant Feeding: In vitro and In vivo Evaluation. Asian-Australasian Journal of Animal Science 28(3): 343-350.

Lana, JB, ME Russell, V Amburgh. 1998. The role of $\mathrm{pH}$ in regulating ruminal methane and ammonia production Journal of Animal Science, 76:21902196

Licitra, G, TM Hernandez and PJ Van Soest. 1996. Standardization of procedures for nitrogen fractionation of ruminant feeds. Animal Feed Science Technology 57:347-358.

Mirzaei-Aghsaghali, A and N Maheri-Sis. 2008. Nutritive value of some agro-industrial by products for ruminant- A review. World Journal of Zoology 3 (2): 40-46.

National Research Council (NRC). 2000. Nutrient Requirements of Beef Cattle: Seventh Revised Edition: Update 2000. Washington, DC: The National Academics Press.

Nuraini dan ME Mahata. 2009. Pemanfaatan kulit buah kakao fermentasi sebagai Pakan alternatif ternak di daerah sentra kakao Padang pariaman. Padang: Fakultas Peternakan. Universitas Andalas.

Samadi, Y Usman and M Delima. 2010. Kajian potensi limbah pertanian sebagai pakan ternak ruminansia di Kabupaten Aceh Besar. Jurnal Agripet 10(2): 45-53.

Samadi and P Yu. 2011. Dry and moist heatinginduced changes in protein molecular structure, protein subfraction, and nutrient profiles in soybeans. Journal of Dairy Science 94:60926102.

Samadi, K Theodoridou and P Yu. 2013. Detect the sensitivity and response of protein molecular structure of whole canola seed (yellow and brown) to different heat processing methods and relation to protein utilization and availability using atr-ft/ir molecular spectroscopy with chemometrics. Spectrochimica Acta Part A: Molecular and Biomolecular Spectroscopy 105 :304-313.

Samadi, S Wajizah and Sabda. 2015a. Peningkatan kualitas ampas tebu sebagai pakan ternak melalui fermentasi dengan penambahan level tepung sagu yang berbeda. Agripet 15(2):104111.

Samadi, S Wajizah, Y Usman, D Riyatsyah and Z Al Firdausya. 2015b. Improving sugarcane baggase as animal feed by amoniation and followed by fermentation with Trichoderma harzianum (in vitro study). Journal of Animal Production 18 (1):14-21. 
Samadi, S Wajizah, and AA Munawar. 2018. Rapid and simultaneous determination of feed nutritive values by means of infrared spectroscopy. Tropical Animal Science Journal. 41(2): 121-127.

Seo, J, JK Jung and S Seo. 2015. Evaluation of nutritional and economic feed values of spent coffee grounds and Artemisia princeps residues as a ruminant feed using in vitro ruminal fermentation. Food Science and Technology 3:e1343.

Smith, P, and PJ Gregory. 2013. Climate change and sustainable food production. Proceedings of Nutrition Society 72:21-28.

Theodorou, MK, BA Williams, MS Dhanoa, AB McAllan and J France. 1994. A simple gas production method using a pressure transducer to determine the fermentation kinetics of ruminant feeds. Animal Feed Science Technology 48:185-197.

Tilley, JMA., and RA Terry. 1963. A two-stage technique for the in vitro digestion of forage crops. Grass and Forage Science 18:104-111.

Van Soest, PJ, JB Robertson and BA Lewis. 1991. Methods for dietary fiber, neutral detergent fiber, and nonstarch polysaccharides in relation to animal nutrition. Journal Dairy Science 74:3583-3597.

Wahyono, DE and R Hardianto. 2004. Pemanfaatan Sumber Daya Pakan Lokal Untuk Pengembangan Usaha Sapi Potong. Lokakarya Sapi Potong. Pp: 66-76.

Wajizah, S Samadi, Y Usman and E Mariana. 2015. Evaluasi nilai nutrisi dan kecernaan in vitro pelepah kelapa sawit (oil palm fronds) yang difermentasi menggunakan Aspergillus niger dengan penambahan sumber karbohidrat berbeda. Agripet 15 (1): 13-19

Yulistiani, D, W Puastuti, dan EW Supriati. 2012. Pengaruh Berbagai Pengolahan Terhadap Nilai Nutrisi Tongkol Jagung: Komposisi Kimia Dan Kecernaan In Vitro. JITV. 17:59-66. 